\title{
ПРОСТОРНЕ ГРАНИЦЕ У СВЕТЛУ ПРИЗРЕНСКО-ТИМОЧКИХ ГОВОРА
}

У раду су са лексичко-семантичког становишта представљене именичке лексеме којима се означавају границе простора на српском говорном подручју, с посебним освртом на ареал југоисточне Србије. Полазећи од значењског спектра лексеме граница забележеног у РСАНУ и РМС, аутори на основу сазнања потврђених у дијалекатским речницима с простора призренско-тимочке дијалекатске области, анализирају и пореде лексичке јединице које у семском саставу имају компоненту значења „граница простора”.

Кључне речи: српски језик, призренско-тимочка дијалекатска област, лексема граница.

Ишчитавајући научни опус П. Пипера који кроз призму односа језика и простора доприноси успостављању теорије семантичких локализација, и који у „простору језика испитује семантику и синтаксу конструкција са просторним значењем и граматичку архитектуру израза којима се различита непросторна значења исказују према просторним критеријумима" [Пипер, 2008: 307], наишли смо на утемељење појма граница као простора „којим се завршава једна појава, и од којег почиње друга, а у којем се додирују два ентитета, две посебности... Другим речима, граница, била она просторна, друштвена, културна или нека друга, показује докле нешто јесте, и одакле нешто није више исто" [Исто: 308]. Будући да опсежна истраживања П. Пипера првенствено обухватају разматрања о граматичким средствима исказивања значења границе у српском језику, наша пажња ће у овом раду бити усмерена на семантички потенцијал лексеме граница и осталих лексичких јединица чија се примарна семантичка реализација односи на именовање границе простора у традиционалној култури. Ослањајући се на још једну констатацију П. Пипера [2001: 8] о условљености типа језичке структуре животним простором говорних представника, наше истраживање базираће

\footnotetext{
${ }^{1}$ anasavic81@gmail.com

2 Прилог је настао у оквиру пројекта „Дијалектолошка истраживања српског језичког простора" (ЕДБ 178020), који у целини финансира Министарство просвете, науке и технолошког развоја Републике Србије.
} 
се на значењској анализи лексичких јединица којима се означавају границе простора на српском језичком простору, с посебним освртом на ареал југоисточне Србије и говоре призренско-тимочке дијалекатске области.Територија југоисточне Србије представља пространо планинско подручје, прилично изоловано и на рубу друштвених и цивилизацијских токова, које није претрпело велике културне и етничке притиске те је у великој мери сачувало своје особености и традицију. У том смислу, ова географска целина јесте прилично хомогени културни ареал, репрезентован, између осталог, и кроз различите језичке чињенице.

Користећи материјал забележен у РСАНУ и РМС за идентификацију лексичких јединица заснованих на семантичкој компоненти „граница простора", циљ нашег рада јесте да на основу дијалекатских речника с подручја призренско-тимочке дијалекатске области сачинимо што потпунији увид у семантичку структуру лексичког фонда за означавање границе простора у говорима југоисточне Србије. Наше истраживање у извесној мери кореспондира истраживању које је спровео Н. Богдановић бавећи се земљописном лексиком југоисточне Србије [Богдановић, 2008], те ћемо стање регистровано у дијалекатским речницима допуњавати резултатима репрезентованим у овој студији.

Експлицирање грађе започели смо почев од општепознатог назива граница. Функционални значај појма границе условљава велики семантички потенцијал концепта границе, „који се испољава у значењима лексеме граница, у могућностима спојивости те лексеме са другим речима и облицима и са лексемама са блиским значењима..." [Пипер, 2008: 308]. Полисемантичка садржинска структура лексеме граница обједињује низ различитих значења која су повезана истоименом интегралном семом. Из синхронијске перспективе, према РСАНУ [1965: 567-568], примарно значење лексеме границ̧а je: а. „линија (каткад појас земљишта) која раздваја различита подручја”, б. „погранични крај, гранично подручје; крајина” и в. „подручје, територија уопште (тј. оно што је обухваћено границама (1a))". Из примарног значења су се различитим механизмима полисемије развиле и бројне секундарне семантичке реализације. ${ }^{3}$ У првом реду, дошло је до метафоричког преноса имена на основу функционалне сличности и везивања појма граница за конкретан објекат, који је у РСАНУ [1965: 568] дефинисан као „камен међаш или какав други знак којим се обележава докле се простире неко подручје”.

Од речника с призренско-тимочког говорног подручја једино Речник говора Лужнице има одредницу гра́ница у значењу „линија која обележа-

\footnotetext{
${ }^{3}$ Иако овом приликом нису у фокусу наше пажње, запажамо да су се метафоричким асоцијацијама заснованим на трансформацијама конкретно-апстрактно развила и фигуративна значења потврђена у РСАНУ (1965: 568): а. „крај, завршетак, мера до које се нешто протеже, преко које се не може, ограничење”; б. „непосредни почетак, непосредна блискост, настајање нечега”, в. „оно чиме се одређује обим, опсег нечега, чиме је нешто обухваћено, оквир, одређена, уобичајена норма”, г. „прекретница, преокрет, прелом”.
} 
ва докле се нешто простире, која дели два пространства, државна међа": - Приччају да је бу́гарска војска́ прешла́ гра́нищу, и да че ни Бу́гари па́к окупи́рају. Сла́бо и́демо у та́ј села́, која́ су бли́зо до бу́гарски гра́ницу [Ћирић, 2018: 130]. У Речнику говора јабланичког краја нема овакве одреднице, али је у илустративном материјалу у вези с одредницом жандоме́рија потврђена лексема гра́ница: - Óн је служи́ја жандоме́рију, там на гра́нииу с македо́нско [Жугић, 2005: 86].

Фокусирајући се на значења којима се имплицира просторно ограничење, с лексемом граница у однос делимичне синонимије ступа лексема међ $а$, у РСАНУ [1984: 300-301] дефинисана као а. „гранични појас, гранична линија, обележена каменом међашем или каквим другим знацима, која раздваја имања двају власника; граница између два подручја, две државе; подручје, територија обухваћена том границом”, б. „заст. погранични крај, погранично подручје; крајина; исп. граница (1б)” и в. „ивица, крај, руб”. Међутим, пошавши од значења заснованих на колективној свести говорника, у традиционалној култури граница примарно означава „линију као границу површине”, док се међом првенствено конотира „гранични простор између две површине". Иако се ове лексеме не могу сматрати апсолутним еквивалентима, лексема међа је у српском књижевном језику углавном потиснута називом граница. С друге стране, док лексема граница у говорима призренско-тимочке дијалекатске области бележи само спорадичну употребу, лексема међа, односно различите фонетске и творбене варијанте забележене су широм говорног подручја. У фундусу података за Срnски дијалектолошки атлас на призренско-тимочком ареалу потврђене су: ме́ђа/ међá, ме́иа/ме́u’a/меца́, што кореспондира чињеницама посведоченим у већини дијалекатских речника. У Црнотравском речнику лексема међа́ забележена је у значењу „гранична линија, гранични појас између два имања, или сеоских атара": - Између́ мојý и Ста́врину пади́ну међá и́де од они́ја голе́м белутра́к, преко кру́шку, низ ва́лог па на изво́р [Стојановић, 2010: 448]. У истом значењу фонетска варијанта меца́ потврђена је у Тимочком дијалекатском речнику: - Тужи́чу га, преора́л ми меиу́ [Динић, 2008: 410]; Речнику пиротског говора: - Прео́рује, поме́ра ме́ие, ло́ш чове́к [Златковић, 2014: 453]; и Речнику говора Лужнице: - Сва́ко село́ зна́је ме́ие на сво́ј ámap [Ћирић, 2018: 464]. У Речнику пиротског говора иста семантичка реализација потврђена је у вези са изведеницом меца́нка: - За мей́́нку се на́ши несу́ кара́ли, пази́ли су на то́j [Златковић, 2014: 453]. ${ }^{4}$

Лексема међá/меца́ јавља се и у значењу „камен или други сигуран знак који одређује границе неког имања": - Овде́-е била́ поби́ена међá јóm од мое́га пра́мдеду, ал Ми́лен гу помери́л два́ скро́ка у мое́. - Неки́ ни извади́л међу́ и врљи́л гу у трња́к. [Стојановић, 2010: 448]; - Ка́мик на меиу́ се

\footnotetext{
${ }^{4}$ Н. Богдановић [2008: 465] у значењу „граница поседа” бележи варијанте: ме́ђа/мещá, међáк/ меиа́к.
} 
зове́ меца́ [Златковић, 2014: 453]; [Богдановић, 2008: 465]. Иста семантичка реализација распознаје се код лексема мецни́к: - Овде́ че да уко́nамо меини́к [Динић, 2008: 410]; - Меини́к там и́ма, и́ма леска́ [Златковић, 2014: 454]; и меца́p [Ћирић, 2018: 464]. За означавање природне просторне границе, као и различитих реалија на њој у употреби су и творбене варијанте међáк/меиа́к: - Бе́рем др́ва по меца́ци, у а́логу не ула́зим [Динић, 2008: 410]; - Меца́к је сло́г, стена́, шу́ма, ро́вина, од при́роду меиа́. - Меца́к је бразда́, и ками́к на ћотети́ја [Златковић, 2014: 453].5

На основу забележених семантичких реализација лексема̄ границиа и међа [РСАНУ, 1965: 567-568; 1984: 300-301] запажамо да се у једном од значења развија блискозначност с лексемом крајина, иначе територијалним термином за именовање пограничне области неке државе. На блиску семантичку везу међу овим лексичким јединицама упућује се још у РЈАЗУ [1887-1891: 886], где се одредница granica дефинише у значењу „mjesto dokle se proteže nešto prostrano (najčešće zemlja, država), pa po tome i mjesto gdje se onakovo što dotiče s drugijem čim; uprav bi bila linija bez debeline, ali se gdjegdje ovako zove i dio (zemlje, države) koji je pri (pravoj) granici - isporedi međa, kraj, krajina”. У РСАНУ [1978: 404] лексема крајина је дефинисана као „погранична државна област са уређеним системом војне одбране, гранично подручје, граница", док у прегледаним дијалекатским речницима нема потврде овој лексеми. Конфронтирањем значења која су се развила у колективној свести у вези са лексемама крајина и граница можемо говорити о постојању само делимичне синонимичности, јер се значење лексеме крајина везује за шири простор на граници који има и историјску димензију.

И лексема крај, која је у основи назива крајина, примарно се везује за семантичку категорију простора, означавајући крајњу линију која чини границу какве површине или део површине уз ту линију [РСАНУ, 1981: 400]. Међутим, у грађи коју бележе дијалекатски речници „претежу примери са темпоралним значењем почетка за лексему краj, а ово специфично значење поменуте лексеме ређе се среће у месном смислу" [Милорадовић, 2001: 459]. Прегледом речника утврдили смо да се месно значење распознаје у изразу од крај до крај, у значењу „од почетка до краја”: - Oт кра́j до кра́j [Јовановић, 2004: 448]; - От кра́j до кра́j њи́вву, ники све́ ти́кве да ми обере́ [Жугић, 2005: 168]; - Окоси́л сам у Стра́ғе от-кра́j до кра́j [Стојановић, 2010: 392]. Забележено је и значење „крајња тачка која чини међу простирања какве површине": - Мори́зата подгápa на они́jа кра́j [Златковић, 2014: 390]; - И́дете прекај кра́j, немо́j да га́зите по среди́ну [Ћирић, 2018: 402]. Н. Богдановић [2008: 461] у вези с лексемом кра́j бележи значење „земљиште на граници неког подручја".

\footnotetext{
${ }^{5}$ Исте лексеме потврђују и Златановић [1998: 226]; Ћирић [2018: 464]; Богдановић, [2008: 465], али без илустративног материјала.
} 
На призренско-тимочком дијалекатском подручју фигурира и истокорени назив кра́иште/кра́јиште којим се именује „крај неке површине (платна, њиве, атара, области и сл.)". Тако у Тимочком дијалекатском речнику налазимо потврду: - Што́ неси́ доора́л кра́јиштата? [Динић, 2008: 358], у Црнотравском речнику: - Ти ко́си по кра́јишта, а ја ћу куде́-е дебе́ла трава́ [Стојановић, 2010: 392]. У Речнику пиротског говора: - Пази́ да не истрчи́ влкат из кра́јиштето и да ти гра́бне овиу́ [Златковић, 2014: 390] и у Речнику говора Лужнице: - Пази́ да не оста́не непоо́рано прекај кра́јишта, да се не сме́jу комши́jе [Ћирић, 2018: 402]. Фонетска варијанта кра́иште у истом значењу потврђена је у Речнику села Каменице код Нима: - И́ди по кра́иште, да не га́зиш по бачко́љ. - На де́л ми па́дла са́мо кра́ишта од њи́ве и бра́ништа [Јовановић, 2004: 448] и Речнику тимочког говора [Кожељац, 2014: 234].

Блискозначност с лексемом кра́иште/кра́јиште распознаје се у семантичким реализацијама бројних лексичких јединица које у вези с разграничавањем имања, њива, пашњака, шума, ливада проналазимо у раду Љ. Протића [1937: 62]: брезина, брид, валуга, долина, јарак, јаруга, јендек, канал, коса, муше, ограда, отар, перда, разор, ред, састав, сидек, синор, склад, слог, удут.

Већину ових лексема и њихових секундарних семантичких реализација које се односе на различита просторна разграничавања потврђују РСАНУ и РМС, али не и речници с подручја призренско-тимочке дијалекатске области. С тога ћемо се осврнути само на сазнања која су у њима забележена и у том смислу релевантна за наш аспект истраживања.

Лексему синор која је у РМС [1973: 770] дефинисана као „међаш, сеоска међа, гранища" бележи једино Богдановић [2008: 478] у спецификованом значењу „место на граници економског (обрадивог) дела атара и оног 'изнад села' под пашњацима'.

У призренско-тимочким говорима граница између обрадивих површина најчешће се означава лексемом сло́г, која је у РМС [1973: 863] дефинисана као „земља између два разора на њиви; узан комад земље у башти, повртњаку и цветњаку, леја". У речницима с призренско-тимочког говорног подручја лексема сло́z потврђена је у значењима која се односе на уско необрађено земљиште, које је остављено као граница између двају поседа и које се налази на узвишици: „њиве степенасто поређане и с уздигнутим међама” [Златановић, 1998: 374]; „међа између винограда, обично између доњег и горњег винограда; облик каскаде": - Милутúн ко́na ло́jзе до сb́м сло́z [Јовановић, 2004: 622]; „хоризонтална међа облика каскаде између две њиве у брдовитом пределу": - Дьни́с слого́ви зара́сли у трња́щ̧и и у купиња́щ̧и. - Кьд смо били́ дейа́ сло́гови су били́ по́висоћи од на́с, по́сле кьд су биле́ сеља́чће ра́дне за́друђе мло́ги сло́гови су со́рани [Динић, 2008: 768]; „разделница између имања, где се од дугогодишњег орања земља надигла": - Hámo-е до 
сло́г, по(д)-ило́г нека о́н ко́си, а сливи́, што-е на сло́г, ће за́еднички да бе́ремо [Стојановић, 2010: 865]; „међа између суседних парцела, каткад под трњем, травом или камењем": - Комши́је смо с њи́ве, сло́г ни де́ли [Златковић, 2014: 414]; „каскада обрасла трњем или травурином”: - Ови́ја сло́гови све́ ура́сли у тр́ғе [Ћирић, 2018: 963]; „горња (терасаста) међа њива на нагнутом земљишту" [Богдановић, 2008: 479].

На основу одређења експлицираних у РМС лексема слог остварује синонимију с лексемом склад „међа од неузоране земље између двеју њива” [PMC, 1990: 803]. На истозначност се упућује и у истраживањима Н. Богдановића [2008: 479]. У речницима с призренско-тимочке дијалекатске области нема потврде оваквом значењу. Једино је у Речнику пиротског говора скла́d дефинисан као „жбун; изданак, стабло”: - До они́ја скла́д остави́ водýmy [Златковић, 2014: 400], што би се са становишта семантичког тумачења могло повезати с конкретним знаком на граници међу имањима.

Земљано узвишење на граници поседа означава се и лексемом мађи́ла [Богдановић, 2008: 464] ; с којом је у вези и именовање камена или каквог другог знака на граничном простору мађи́лка/међи́лка: [Богдановић, 2008: 464]; - Сва́ћи је мора́л да от ка́мен напра́ви мађи́ле, и да ји с кре́ч закре́чи, да они́ из авио́н сни́ме ме́ие. - Глава́ се губи́ла ако неко́ј некоме́ поме́ри међи́лку, а са́ јо́ш ма́лко па не́че да се позна́ва и њи́вете где су биле́ [Ћирић, 2018: 446, 258].

Граница поседа коју чини део њиве који остане неузоран, јер се налази на крају именује се лексемом у́зглавница [Богдановић, 2008: 484].

Бразда која се налази у средини њиве и представља границу орања, делећи тако њиву на две половине, назива се разор [РМС, 1973: 388]. Потврду овом значењу налазимо у многим речницима: - Jóm да пу́штим разо́p и завршиил сам ора́ње [Јовановић, 2004: 593]; - Тра́ктор пра́и голе́м разо́р, едва́ га по́сле некако́ затр́пам с мати́ку [Динић, 2008: 709]; - Ра́зор не мо́же ни дрља́ча да пора́вни [Ћирић, 2018: 877]. ${ }^{7}$ У Речнику пиротског говора потврђена је изведеница ра́зорак: - Вода́та и́де низ ра́зорак и земља́та наmúнуује [Златковић 2014: 342].

Другачије мотивације су именовања земљишта која представљају средишњи део неког подручја, шуме, њиве, планинске косе. У Речнику тимочког говора проналазимо лексему осре́дак/осреда́к [Рајковић Кожељац, 2014: 359], док је у Тимочком дијалекатском речнику у синонимном значењу забележена лексема среди́s [Динић, 2008: 755].

Јарак, јаруга, јендек и канал 8 јесу граничне површине између имања

\footnotetext{
${ }^{6}$ Код Динића [2008: 378] је забележено потпуно супротно значење „хумка”: - Туј су мађи́ле, куј йи зна́е из кое́ до́бо.

${ }^{7}$ Исту лексему бележи и Златановић [1998: 337], али без илустративног материјала.

${ }^{8}$ Будући да су сви дијалекатски речници конципирани као диференцијални, изостало
} 
у виду дубоких удубљења стрмих страна, често испуњених водом [РСАНУ, 1973: 570, 588-589, 729; РСАНУ, 1975: 184]. У том значењу различити облици ових лексема забележени су и на призренско-тимочком терену: jápau, „овећи шанац, јарак” [Динић, 2008: 299], јеру́га: - Не могá да прери́пим јерý гу, па па́до у њý [Јовановић, 2004: 437]; - Не́ћи врљи́л ли́псалу коко́шку до́ле у јеру́zу [Динић, 2008: 302]; - Пропа́дал ни пу́m, јеру́zа до јеру́гу [Стојановић, 2010: 346], а́ндак: - Докле пројдо́ они́ја голе́ми а́ндак на[д]-цело́, но́ге ми се оце́коше [Стојановић, 2010: 32]; е́ндак: - Упа́дал са све́ биичи́лу у е́ндак [Динић, 2008: 170], енде́к: - Едва́ се изву́кал из енде́к [Јовановић, 2004: 394]; - Сва́ки да си иско́па енде́к пред по́рту да мо́ж вода́ да оти́ца, да му се не пу́ни обо́р с во́ду [Жугић, 2005: 84], - Утрокољи́л се пија́н у енде́к [Стојановић, 2010: 211], јендь́к/је́ндак: - Ty[j]-и́ма пу́но јендации [Стојановић, 2010: 346]; - Ископа́л је́ндак на мо́јето, помери́л меиу́ту [Златковић, 2014: 359], јенде́к/је́ндек: - Не мога́ да прери́пим јенде́к, па упа́до у ње́г [Јовановић, 2007: 532]; - Вади́мо је́ндек, гради́мо юи́вуту од ту́ја стра́ну [Златковић, 2014: 359]. Сличног изгледа јесте и про́коп, граница између два атара настала ископавањем земљишта [Кожељац, 2014: 465].

Једно од секундарних значења лексема долина јесте „граница између ливада" [РСАНУ, 1966: 501]. У речницима с призренско-тимочког говорног подручја потврђени су облици: до́л [Динић, 2008: 140; Богдановић, 2008: 453; Златковић, 2014: 161], доли́на [Богдановић, 2008: 4 53]; [Стојановић, 2010: 181], као и синоним пади́на [Јовановић, 2004: 524; Жугић, 2005: 261; Динић, 2008: 528; Стојановић, 2010: 624; Ћирић, 2018: 653; Богдановић, 2008: 453]. Међутим, значење ових лексема примарно се везује за широке и питоме пределе у брдовитим крајевима, док се семантичка реализација којом се указује на просторно разграничавање двеју површина распознаје код деминутивног облика пади́нка ,плитко улегнуће у равничарском пределу" - Прво покоси́ пади́нкуту, ел та́м е на́јвисока трава́ [Динић, 2008: $528]^{9}$ и аугментатива па́далиште ,удубљење у земљи, удолина, котлиница, вртача, клизиште” [Богдановић, 2008: 470]. ${ }^{10}$

Н. Богдановић [2008: 484] у значењу ,дубља долина између два узвишења” бележи лексему у́вала, а у значењу „земљиште између две долине” лексему раздо́лие [Богдановић, 2008: 476].

Примарно значење лексеме ограда јесте „оно чиме је што ограђено, одвојено од другог чега (о земљишту, забрану, дворишту и сл.)", из кога

је бележење многих лексема које значењем или обликом нису представљале битнији дијалекатски спецификум.

9 Деминутивне облике потврђују и: Јовановић, 2004: 524; Жугић, 2005: 261; Стојановић 2010: 625; Ћирић, 2018: 653.

${ }^{10}$ Иако у речницима нема потврде о лексеми де́л и њеној семантичкој реализацији која упућује на просторно ограничење, могло би се говорити о компоненти значења којом се сугерише на висинску границу која дели два простора - копнени и ваздушни. 
се развија и фигуративно значење „преграда, граница” [РМС, 1969: 909]. Ограда у значењу преграде може бити различитог изгледа, али се под њом подразумева „све што на њу личи и што функционише као она” [Марковић, 1991: 64], односно средство које служи као заштита на ивици, које има улогу преграде или границе. На призренско-тимочком дијалекатском тлу позната су оба значења, али ћемо се усредсредити на значење којим се дефинише конкретан објекат за просторно ограничавање: о́градња/óграња: - Њи́на је о́градња окол авли́ју напра́ена од ка́мен [Динић, 2008: 480, 481]; - И́ма пла́u u и́ма зад ку́ћу у́баву о́градюу [Златковић, 2014: 24], о́граџа: - Сьг пра́имо о́граиу од ка́мен, скла́ғьамо та́рабе [Динић, 2008: 481], о́грађа: - Скрши́ли ни о́грађу на гради́ну и пушти́ли сто́ку да уле́зне [Стојановић, 2010: 558]. Н. Богдановић у истом значењу бележи лексеме: о́града,,међа земљишта којом се обележава посед и чува од штете коју може нанети стока" [2008: 469], за́zрай [2008: 455], док се „покретна ограда за овце” означава лексемом за́мет [Богдановић, 2008: 455].

Посебну врсту ограде представља перда [РМС, 1971: 388]. У призренскотимочким говорима потврђен је облик перде́ у значењу „ограда на тераси или дивани": - Тури́ла ћели́ми на перде́ [Јовановић, 2004: 532]; - Ле́ти распро́стрем чр́ђе по перде́. - Не нава́љај се преко перде́, мо́ж да па́днеш! - Њи́на дива́на јóm не́ма перде́, зато́j што јо́ш не́ гото́ва [Динић, 2008: 541]; -Изне́си ир́ге на перде́ да се ветре́ју [Стојановић, 2010: 637]; - С вре́ме на вре́ме ир́ђе изнесе́м, ишчу́кам и про́стрем на перде́ да се прове́тре [Ћирић, 2018: 670].

Бројност назива за именовање границе простора у говорима призренско-тимочке дијалекатске области условљена је врстом самог ентитета који се ограничава и природом границе која се успоставља. Анализа је показала да почев од државних граница, преко граница између поседа, природних граница ограничења простора, те граница поделе/разделе простора, именовања могу бити разноврсна. Наиме, различитим лексичким јединицама означавају се и различите врсте просторних граница. За границе простора употребљавају се: гра́ниц̧а, ме́ђа, сино́р...; за гранични простор, тј. за простор на граници: гра́ница, ме́ђа, кра́јина, кра́јиште...; природне границе простора именују се лексемама: до́л, доли́на, јеру́га...; за именовање објеката с функцијом границе забележене су лексеме: о́града, о́грађа, пло́т...; тачке на граници простора именују се лексемама: ме́иа, мецни́к, међа́р...; а постоји и могућност дескриптивног исказивања границе: од крај до крај.

\section{Литература}

Богдановић, 2008: Н. Богдановић. Земљописна и юој сродна лексика југоисточне Србије. Српски дијалектолошки зборник LV. Београд: Српска академија наука и уметности и Институт за српски језик САНУ, 433-518. 
Динић, 2008: Ј. Динић. Тимочки дијалекатски речник. Београд: Институт за српски језик САНУ.

Жугић, 2005: Р. Жугић. Речник говора јабланичког краја. Српски дијалектолошки зборник LII. Београд: Српска академија наука и уметности и Институт за српски језик САНУ, 1-470.

Златановић, 1998: М. Златановић. Речник говора јужне Србије. Врање: Учитељски факултет.

Златановић, 2011: М. Златановић. Речник говора југа Србије. Врање: Аурора.

Златковић, 2014: Д. Златковић. Речник пиротског говора 1-2. Београд: Службени гласник.

Јовановић 2004: В. Јовановић. Речник села Каменице. Српски дијалектолошки зборник, LI. Београд: Српска академија наука и уметности и Институт за српскохрватски језик САНУ, 313-688.

Јовановић 2007: В. Јовановић. Додатак речнику села Каменице код Нима. Српски дијалектолошки зборник, LIV. Београд: Српска академија наука и уметности и Институт за српскохрватски језик САНУ, 403-520.

Марковић, 1991: Р. Марковић. Гранање значења речи које означавају кућу и њене делове. Наш језик 29, 1-2, Београд: Институт за српски језик, 1991, 55-76.

Милорадовић, 2001: Милорадовић, Софија. Почетак од краја. Зборник Матице српске за филологију и лингвистику XLII. Нови Сад, 457-461.

Пипер, 2001: P. Piper. Jezik i prostor. - 2. dopunjeno izd. - Zemun: Biblioteka XX vek.

Пипер, 2008: П. Пипер. Граматика границе. Јужнословенски филолог LXIV. Београд: Српска академија наука и уметности и Институт за српски језик CAHУ, 307-322.

Протић, 1937: Љ. Протић.. Разграничавање имања. Гласник Етнографског музеја, књига 12. Београд: Државна штампарија Краљевине Југославије, 61-70.

Рајковић Кожељац, 2014: Љ. Рајковић Кожељац. Речник тимочког говора. Неготин: Књижевно-издавачко друштво Лексика.

PJA3У, 1880-1976: Rječnik hrvatskoga ili srpskoga jezika I-XXIII. Zagreb: Jugoslavenska akademija znanosti i umjetnosti.

PMC, 1967-1976: Речник српскохрватскога књижевног језика I-VI. Нови Сад: Матица српска.

РСАНУ, 1959-2010: Речник српскохрватског књижевног и народног језика IXVIII. Београд: Српска академија наука и уметности.

Стојановић, 2010: Р. Стојановић. Црнотравски речник. Српски дијалектолошки зборник LVII. Београд: Српска академија наука и уметности и Институт за српски језик САНУ, 9-1060.

Ћирић, 2018: Љ. Ћирић. Речник говора Лужнице. Српски дијалектолошки зборник LXV. Београд: Српска академија наука и уметности и Институт за српски језик САНУ, 1-1166. 
Ana R. Savić-Grujić

Jovana D. Bojović

\title{
SPATIAL BORDERS IN THE LIGHT OF THE PRIZREN-TIMOK SPEECH
}

\begin{abstract}
The paper provides a lexical-semantic view of the representation of the nominal lexemes which are used to denote the borders of space in the Serbian areal, with a special look at the areal of South-East Serbia. Starting from the semantic spectrum of the lexeme граница, as recorded in the SASA Dictionary and the MS Dictionary of the Serbian Language, the authors have, based on findings confirmed in the dialectical dictionaries of the area of the Prizren-Timok dialect zone, analyzed and compared the lexical units whose semic composition contains the component of meaning of "spatial border".
\end{abstract}

Key words: the Serbian language, Prizren-Timok dialect zone, lexeme border. 